\title{
THE RELEVANCE OF GOD'S COVENANT FOR A REFORMED THEOLOGY OF RELIGION ${ }^{1}$
}

\author{
Dirk Griffioen \\ Utrecht Mission, Utrecht
}

\begin{abstract}
ABSTRAK: Dalam wahyu Allah, struktur perjanjian yang mencakup janjijanji Allah dan jawaban Israel akan janji tersebut. Di dalam perjanjian Allah telah menyatakan diri-Nya secara pribadi baik kepada individu dan kepada umat pilihan-Nya. Di dalam teologi agama yang dikemukakan Hendrik Kraemer, ada dua macam agama: agama (nubuatan) berdasarkan wahyu Allah, dan yang lain agama-agama (natural) yang berdasarkan usaha-usaha untuk menggenggam identitas dirinya yang sejati dengan realitas ilahi, hal ini diberi istilah "realisasi diri yang trans-empiris". Apakah esensi agama yang berdasarkan penyataan diri Allah? Penyataan Allah adalah sumber satu-satunya akan semua pengetahuan mengenai spiritualitas sejati dan keselamatan di dalam Kristus. Alkitab adalah saksi akan wahyu Allah kepada para nabi dan para rasul sebagai kriteria akan seluruh kebenaran agamawi. Alkitab mengaitkan sejarah penebusan, memberikan dasar untuk iman pribadi, dan merupakan satu-satunya pegangan untuk hidup dan pelayanan dari komunitas Kristen. Dari titik tolak inilah saya mencoba untuk menganalisis konsep alkitabiah akan kebenaran agama sebagai satu standar untuk menentukan agama-agama, dan untuk memberikan jawaban yang sesungguhnya kepada wahyu diri Allah.
\end{abstract}

KATA KUNCI: perjanjian, wahyu, iman, agama.

1 Presentation for the WRF/REIC Conference Jakarta, March $7^{\text {th }}-12^{\text {th }}, 2016$. 
ABSTRACT: In God's Revelation, the structure of the covenant consists of God's promises and Israel's answer to them. In the covenant God has revealed Himself personally to both individuals and his chosen people. In the theology of religion developed by Hendrik Kraemer, there are two types of religion: The (prophetic) religion based on God's revelation and the other (naturalist) religions are based on efforts to grasp the identity of his real self with divine reality, this is called as 'trans-empirical self realization'. What is the essence of religion based on God's self revelation? God's revelation is the only source of all knowledge about true spirituality and the salvation in Christ. The Bible as the witness of God's revelation to prophets and apostles is the criterion of all religious truth. The Bible relates the history of redemption, gives a foundation to personal faith, and is the only guidebook to the life and work of the Christian community. From this starting point I try to analyze the Biblical concept of religious truth as the standard for determining religions, and to give a real answer to God's self revelation.

KEYWORDS: covenant, revelation, faith, religion.

\section{What the Covenant Stands for}

The Westminster Confession of Faith drawn up in $1646^{2}$ together with the Belgian (or Netherlands) Confession (originally the French Confession de Foi, written by Guido de Brès, 1562) presents the idea of God's covenant as the deepest core in God's revelation to prophets and apostles. They are based on God's promises in the Bible. Throughout the history of the church we discover that there are theologians who use the idea of the covenant as a

\footnotetext{
2 This WCF which was designed by the Anglican Church is widely accepted by the Presbyterians as standard containing the system of doctrine taught in both Britain and NorthAmerica. Although very Presbyterian church adopted this standard and made some revisions. The (Dutch) Belgic Confession is one of the standards of faith for the Reformed Churches in Europe and North America. The text of the Belgic Confession was revised many times and translated in many languages.
} 
consistent hermeneutic principle to understand Scripture. As James I. Packer puts it:

It is a hermeneutic that forces itself upon every thoughtful Biblereader who gets to the place, first, of reading, hearing, and digesting Holy Scripture as didactic instruction given through human agents by God himself, in person; second, of recognizing that what the God who speaks the Scriptures tells us about in their pages is his own sustained sovereign action in creation, providence, and grace; third, of discerning that in our salvation by grace God stands revealed as Father, Son and Holy Spirit, executing in tripersonal unity a single cooperative enterprise of raising sinners from the gutter of spiritual destitution to share Christ's glory for ever; and, fourth, of seeing that God-centered thought and life, springing responsively from a God-wrought change of heart that expresses itself spontaneously in grateful praise, is the essence of true knowledge of God. ${ }^{3}$

A covenant is a relationship of promises and claims, 'oaths and bonds', which involves mutual commitments, although not necessarily equal. Especially the biblical covenants between God and his people are unilaterally imposed commands, while other covenants are jointly entered. Some requirements are conditional, others are unconditional. Typical for the ancient Middle East treaties is the preambule which identify the treaty maker as the sovereign ('In the beginning, God....,' Genesis 1:1; 'I am the LORD your God, who...,' Exodus 20:2), followed by a historical prologue (Genesis 2-3; see also John 1:1-5). ${ }^{4}$ In Scripture we find this concept of oaths and bonds in a broad variety. The God of Abraham, Isaac and Jacob reveals Himself to his people in a reflection of the well-known partnership relation between two parties: the sovereign-treaty of a king with his subject

\footnotetext{
3 J.I. Packer, An Introduction to Covenant Theology (2012-06-23), Kindle Locations 26-31.

4 All Scripture quotes in this article are from Holy Bible, New International Version (London: Hodder and Stoughton, 1973 and 1991) (Ninth impression).
} 
people(s). In God's covenant the people of God are commissioned to exercise the bonds of the covenant. And finally this world is kept to concede God's reign as righteous and generous. ${ }^{5}$

Since John Calvin (1509-1564) made the concept of the covenant as the core of his theology, the complete literature of the Reformed and Presbyterian Churches are dependent of the idea of 'God's covenant of works' with Adam and Eve and 'God's covenant of grace' in Christ. It is clear that in the teachings of Augustine of Hippo (354-430) we also find the concept of the covenant. Packer mentioned also the names of the Dutch theologian Herman Wits (Witsius, 1636-1708) and his British contemporary John Owen. Both made relevant explorations in covenant theology at the earliest days of the Reformation in western Europe. The later Reformed theology is often called synonymous with covenant theology.

Scholars in the last century made studies in the covenantal motives in Scriptures and the ancient Near East treaties as a model of the relationship between God and man, c.q. sovereign king and his relation with his submitted peoples. The names of scholars who have developed the concept of covenant are George E. Mendenhall and Meredith G. Kline. ${ }^{6}$ The primary word in the Old Testament for a legal kind of arrangement is the Hebrew berith, ${ }^{7}$ in New Testament the writers use the Greek word diatheke, which

\footnotetext{
5 Michael Horton, Introducing Covenant Theology (Grand Rapids: Baker, 2006), 9-10.

6 G.E. Mendenhall, Law and Covenant in Israel and Ancient Near East (Pittsburgh: The Biblical Colloquium, 1955); Meredith G. Kline, The Treaty of the Great King (Grand Rapids: Eerdmans, 1963), also The Structure of Biblical Authority (Grand Rapids: Eerdmans, 1975). Mendenhall proved that the model of the ancient treaties from Hittite's kings (circa 1450-1180 BC) are similar to the 'pact' between God and his people. Cf. M. Horton, Introducing Covenant Theology, 24.

7 The Hebrew word berith refers to both oath and curse. The synonym is chesed, with means loyalty of fidelity, and has a connotation with the term 'emet, truth. The oath-commitment in the berith-covenant we find for example in Deut. 29:12-13, which reads: 12 You are standing here in order to enter into a covenant with the LORD your God, a covenant the LORD is making with you this day and sealing with an oath, 13 to confirm you this day as his people, that he may be your God as he promised you and as he swore to your fathers, Abraham, Isaac and Jacob. Cf. Ezek. 16:8 - I gave you my
} 
means a disposition or a testament. Characteristically the transaction of a covenant centers as a mutual kind of arrangement, sworn in with an oath, while the sanction on trespassing is a curse. Many scholars distinguish by analogy with the Hittite treaties the typical elements in the Biblical covenants. First there is the preambule, identifying the initiator of the treaty. Second aspect is the historical prologue, declaring what the sovereign as the great king has done (for instance Deuteronomy 1:6 - 3). Third element of the covenant are the stipulations (see Exodus 20:18-26; also Deuteronomy 5:2232). And fourth, the stipulations are followed by sanctions that explain what the sovereign would do towards the vassal in case of violation of the rules. The fifth stipulation provides the element of the deposit of the treaty, which refers to the complete covenant (tablet or written scripture) to be dropped in the sacred temple as a witness for both parties, and with the obligation for periodic public reading. ${ }^{8}$ The covenant of Joshua 24 shows exactly the pattern of the Hittite sovereign-vassal treaty. The author identifies Himself as the LORD, the God of Israel, followed by the historical prologue in the Iyou form. Than we hear a short list of the stipulations. The people of Israel are mentioned as witnesses. We find also the obligation of the deposit of the covenant in the sanctuary and the sign of the covenant (the setup of a large stone). All the covenants mentioned in the Bible show that there is a development. Like in Jeremiah 31:31-34 we heard of a 'new' covenant. This raises the question what is new in that covenant, or what is the element that is renewed, or did not exist in the previous treaty. We can determine that the similarities of all the Biblical covenants show continuity: the basis is the same - the grace of God; the purpose is the same (cf. 1 Peter 2:9-10); Initiated

solemn oath and entered into a covenant with you, declares the Sovereign LORD, and you became mine. Cf. Deut. 4:31, 7:12; 8:18. See also the covenant between Jacob and Laban described in Gen. $26: 28$, which was sealed with an oath between the two equal parties.

8 Horton, Introducing Covenant Theology, 25-8. 
by blood (Hebrews 9:6-10:18); the character of divine instruction is the same (Romans 13:8, Galatians 5:14). But there is also some discontinuity between the older and the new covenant: better mediator (without sin, Hebrews 8:6; 9:15; 12:24); better sacrifice (Hebrews 9:6-10:18; Isaiah 42:6; 52:13-53:12); Better provision (the Spirit of God, Ezekiel 36:24-28); Better promise (impartation of a new heart, Ezekiel 36:24-28). ${ }^{9}$ Definitely the covenants mentioned in Scripture are interrelated, show a progressive unfolding of God's revelation in Israel's history. You can call it the backbone to God's unfolding redemptive plan, the source of the religion of God's people.

This covenantal structure arises in the Scriptures from Genesis to Revelation. Although the framework that the Bible provides us remains the same with the basic promise 'I will be your God, and you shall be my people', the form of the covenants in the Scriptures changes from time to time. The Bible moves us to the concept of covenant that all we receive from God is His work of saving sinners for His glory. Packer summarizes the parameters of his view on the covenant: First, the gospel of God is not properly understood, second, the Word of God is not properly understood, and third, the reality of God is not properly understood till it is viewed within a covenantal frame. ${ }^{10}$

In order to explain this Packer mentioned three points here: 1. By the story that it tells, from Genesis to Revelation as His record of the progressive unfolding of His plans to have a people for Himself and to save His world. 2. Scriptures forces us to the conviction that the covenant focuses us on the place it gives to Jesus Christ in God's story. 3. Scripture directs us to the covenantal thinking that there is a special parallel between Adam and Christ as the second Adam, cf. Romans 5:12-18, 1 Corinthians 15:21 f., 45-49.

\footnotetext{
9 Peter J. Gentry \& Stephen J. Wellum, God's Kingdom through God's Covenant (Wheaton: Crossway, 2015), 229-36.

10 Packer, An Introduction to Covenant Theology, Kindle 79-135.
} 
Scriptures forces us to the concept of the explicit declaring of the covenant of redemption, cf. the words of Jesus in the gospel of John. His works and words as doing his Fathers will, are all related to his actual words and works as obedience to His Father's command. ${ }^{11}$

\section{Relation between Canon, Revelation and Covenant}

There is a close relation between canon and covenant. Which is crucial for the reaction required according to the stipulations of the covenant from the people of God. Starting with the covenant of conservation (of the world) with Noah, the covenant of grace with Abraham, the covenant with Israel, starting with Sinaic covenant, and all the developments since then, etc. God regulates, showing the same typical scheme of the ancient treaty. In the stipulations God's promises and obligations, are stable and unchanging: the faith and practical life of his people is the condition for the treaty. ${ }^{12}$

Speaking of the covenant, we must make clear first that this specific form of 'oaths and bonds' come to people by God's revelation. The term revelation deals with how God has revealed or disclosed himself to humanity, or in other words, how he has made himself known. ${ }^{13}$ In Reformed theology it is stressed that the only 'agent' in this process of revealing is the triune God Himself. So the act of uncovering is a genuine, unique and sovereign divine act. The knowledge or truth, whatever is made known comes from God and God speaks to people. ${ }^{14}$ In Greek we have the special word apokaluptein, what comes to one's mind what before was unknown, to uncover or to

\footnotetext{
11 Packer, An Introduction to Covenant Theology, Kindle Chapter VI.

12 See Michael Horton, The Christian Faith, A Systematic Theology for Pilgrims on the Way (Grand Rapids: Zondervan, 2011), 151-5.

13 The word revelation comes from the Latin revelare, what was veiled, has been disclosed, or what was unclear of unknown which has become clear. In Dutch the word is openbaring, cf. German Offenbarung, which literally means 'to make open', laid bare.

14 See Richard J. Plantinga, c.s., An Introduction to Christian Theology (Cambridge: Cambridge University Press, 2010), 51-3.
} 
unveil. This can be defined as the act of revealing, of disclosing. God who communicates with humans in different ways. For instance Theophanies (e.g Genesis 31:11-13; Exodus 3:2-4; Judges 13:3-23; Zechariah 3:1-6); Communications, which includes God's audible voice, dreams, visions, the prophets, and finally through Jesus Himself; Miracles (e.g. Deuteronomy 4:32-36). ${ }^{15}$ We may also think about the acts of God in history. Yet there is a difference between knowing God and knowing about God. In Romans we find the other term for revealing: phaneroo, something what is revealed, of manifest, especially a dramatic disclosure of something not previously known or realized. In a particular way God makes Himself known. ${ }^{16}$ We are dependent on God's Word, and this word has divine authority.

In this article I will not dig into the different kinds of revelation, for instance general and special revelation. I will pass over the whole problem of what we call natural theology, and the problem of analogia entis, the analogy of being (the idea that human reason can demonstrate that God exists, Thomas Aquinas). I will also skip the statement raised by John Calvin in his famous Institutes of the Christian Religion, that knowledge of God is naturally implanted in all human beings. Each person carries a sense of divinity, what Calvin calls a sensus divinitatis, or a semen religionis. What I state for granted is that religion is a universal phenomenon of mankind. The discussion on this statement starts with the minimal religiosity of people who realize that they recognize some being greater than themselves, in the creation or outside the objective world: a transcendent, ultimate or even mysterious. And even in the maximised explanation of Romans 1, that every human has

\footnotetext{
15 R.W. Yarbrough, "Revelation" in T. Desmond Alexander, c.s. eds, New Dictionary of Biblical Theology (Downers Grove: Inter-Varsity Press, 2000), 732-738. Cf. Louis Berkhof, Introduction to Systematic Theology (Edinburgh: Banner of Truth, 1949, 1981), 34-41.

16 In this place I will not explain the special means of or the difference between the terms apokalyptō, phaneroō, epiphainō or related words, which convey the whole spectrum of ways and means through which God discloses himself, his will, and his purposes to his people.
} 
a sense of and knowledge of God as creator and provider of this world. The God 'Who is there', Who is hidden in an inaccessible and incomprehensible majesty, has revealed Himself to humans in a manner that is accommodated to human capacities and limited to what He deems necessary for those human beings. Within the covenant of grace He reveals Himself in Jesus Christ, the final revelation. Newbigin calls this revelation in Christ in history: the total fact of Christ. ${ }^{17}$

For my purpose it is sufficient to realize that the concept of revelation is that God makes Himself known in all his acts of redemption and judgment and in many ways, mainly in prophetic. He explains Himself to humans, directly or via prophets and apostles, under the influence of the Holy Spirit. All God's acts of revelation come to human nature in a historical process. This special revelation is suited to the epoch and the stage of what we call the redemptive history. And finally He reveals Himself in the fact of Christ. Which means that God has spoken, finally, in His Son, in His teaching, His suffering, in His work of atonement, and in the interpretative apostolic testimony. In the OT God had spoken or revealed Himself specially to prepare the coming of Christ, His Son, and Redeemer, who will not repudiate the revelation in the Old Testament, but as the fulfilment of the OT. ${ }^{18}$ Karl Barth who denies both natural theology and general revelation,

17 J.E. Leslie Newbigin, A Faith For his One World (New York \& Evanston: Harper \& Row), 5761.

18 Based on the standards of Avery Dullles, Models of Revelation (Maryknoll: Orbis Books, 2002), 36-97, we state that the concept of revelation can be characterized as historical (God's acts in history, in all the interactions with Israel, including the covenantal schemes, in the incarnation of Christ, and in His relation via the Holy Spirit with the church); the second concept of Dulles is doctrinal. That means God has revealed a set of timeless truths or propositions in the teachings of the Scripture. Plantinga calls this the special revelation which is predominantly a doctrinal deposit of the truth. The third concept is experimental. Which means that the revelation of God to humans is a communication given to humans in a subjective reality. The religious revelation of God's revelation evoke a reaction from the human beings: a development or other experience of God, mankind, man himself and the world. The forth concept Dulles calls the dialectical presence. This model is related to the third concept. The idea is 
emphasizes that God's revelation is exclusively to be found in the Christevent, the fact of Christ. The Bible is the fallible but authoritative pointer to Christ, the Word of God written. Scripture is the faithful witness of God's historical redemptive acts in Christ. The written word of God has its origin, inspiration and authority in God, who revealed Himself to prophets and apostles as human mediators, speaking to the covenant people throughout their history, in culture and language. In the proclamation of the church in faith and confessions, doctrines and sermons, etc., the ministry of the church.

\section{Purpose of God's Revelation}

The ultimate object of all God's revelation, both general and special, is to bring his creation, inclusive humans, to Himself. It is the personal encounter with God that marks the ultimate goal of His revelation, in order to know, to love, to confess and acknowledge in a true faith the name and glory of the eternal Trinity and the power and grace of the divine majesty in the unity of Father, Son and Holy Spirit. The Biblical concept of revelation is not merely that of detached critical reflection of the fact revealed, but also of the subjective, even passionate answer to God's revealed truth about Himself. Revelation provides the answer to fallen man's twofold predicament, what Paul mentioned in Romans 1: man ignores God and therefore himself, and that makes him guilty before God. In creation, and all God's acts, in his creation and in the history of the world there are plenty of references to God, so that men are without excuse (Romans 1:20), although the people know God, they did not answer to Him in a proper way, they

\footnotetext{
that God's revelation always has a dialectical relation with mankind. God is expecting an answer from man. Man has to submit himself to God Who is unlimited sovereign. (See also: Richard J. Plantinga, c.s., An Introduction to Christian Theology (Cambridge: Cambridge University Press, 2010), 56-7.
} 
neither glorify Him as God nor give thanks to Him (Romans 1:21). So one can state that God has revealed Himself in creation and his works efficaciously, but the answer of man was not adequate. ${ }^{19}$

God's revelation in Christ not only makes us knowledgeable but is also intended to make us believers of God, who dependent totally on God. This is the substratum of the religion we call the true religion, the religion of God's people, which is a right and adequate answer of God's revelation, rightly interpreted. Surely the methodology employed in the effort to understand the revelation and also the Scriptures, hermeneutics is a crucial area of theology today. In the last centuries the conservative hermeneutic provides a proper approach to the study of the Bible in a historicalgrammatical way. The principle was: Scripture illuminates and explains Scripture. More recently, we understand the "new hermeneutics" as the task to interpret the Biblical message into contemporary terms, 'translating' the original message into modern culture, seeking the relevancy for the modern listener as the interpreter who is responsible for handling of the text, and to formulate his faith and to direct his religion. Whereas revelation is more or less an objective disclosure, the illumination has to do with subjective apprehension.

\footnotetext{
19 I will not discuss the consequences of sin since the historic fall. Clear is Paul's statement: "There is no-one righteous, not even one. There is no-one who understands, no-one who seeks God. All have turned away, the have together become worthless, there is no-one who does good, not even one." Romans 3:10-12. That means religion of man is in no way capable of coming to God and worship Him in a proper way. Man is not equipped with means of knowing God, unless God reveals him by the acts of revelation any 'true knowledge' of God Himself. (see Gabriel Fakre, The Doctrine of Revelation, a Narrative Interpretation (Grand Rapids: Eerdmans, 1997), 43-60). It is possible to understand Calvin's idea of sensus divinitatis as an ability of each human soul or a gift of God to know God personally. According to Romans 1 the manifestations of God's reality and truth in creation and history are accessible to humans. It may be possible to call this ability a universal illumination. See Bruce A. Demarest, General Revelation, Historical Views and Contemporary Issues (Grand Rapids: Eerdmans, 1982), 227-62.
} 
Given this presuppositions on explaining the Scriptures I will now turn to next part of my article. What is the role of God's revelation for religion, or for any religion? The Dutch linguist and missiologist Hendrik Kraemer (1888-1965) describes revelation as a 'connected series of divine acts', as 'repeated divine initiative' that has 'in the course of history many ideas, concepts and experiences that are subject to the vicissitudes of ordinary human development'. ${ }^{20}$ He also notes 'revelation in its proper sense is what is by its nature inaccessible and remains so, even when it is revealed'. Kraemer says the necessary correlate to the concept of revelation is therefore faith. The only organ for apprehending the revelation is faith, and 'for the same reason faith, in the strictly religious sense, can only be appropriately defined as at the same time a divine gift and a human act.' ${ }^{21}$ God's revelation is 'the presupposition on which the prophetic and apostolic witness of the Bible is built.' Kraemer assures us that 'God's revelation in Christ, according to Biblical Realism, is therefore not only the revelation of God, but also of man. Man is revealed as a being who is in his deepest instincts and desires want to be god.'22 In his later Religion and the Christian Faith, Kraemer repeats this definition of revelation: 'the direct, temporally located self-manifestation of God, valid to all men, by way of word, demand, act or event'. But he admits that for philosophers this definition is not acceptable because 'reaching God through excogitation' is impossible. Biblical religion, founded on revelation are to be distinguished from all other religions by their exclusive truth-claims. ${ }^{23}$ In diverse philosophies and religions are to be found the idea 'that God or the Eternal Mind comes to self-consciousness in

\footnotetext{
20 Hendrik Kraemer, The Christian Message in a non-Christian World (London: Edinburgh House Press, 1938), 61.

21 Ibid., 69.

22 Ibid., 70.

23 Hendrik Kraemer, Religion and the Christian Faith (London: Lutterworth Press), 91.
} 
man when he retires into the inner recesses of his being.' ${ }^{24}$ God's revelation in eo ipso an act of divine condescension. It has pleased God to reveal Himself fully and decisively in Christ. The message of this revelation is clear: repent, believe and adore. (p.119) In this concept of the two 'types' of religion Kraemer leans heavily on Karl Barth and also on Calvin. Further on he distinguishes between the 'religions of revelation' (Judaïsm, Christianty and Islam) with their centre of gravity wholly in revelation. Not in Judaïsm or Islam, but only in God's revelation to prophets and apostles, and finally in Christ, God is truly revealed in Jesus Christ, and at the same time He hid and disguised Himself in the man Jesus Christ. Neither flesh nor blood can reveal it, only God Himself, says Kraemer, with reverence to Matthew 16:1617. Witness is correlated to revelation. As faith is indissolubly connected to revelation and witness. ${ }^{25}$ Kraemer emphasizes that revelation, 'of which Christ as a living Person is the final embodiment, is toto modo different from Religion. Religion speaks about what man thinks of God, Revelation speaks of what God thinks of man.' 26

On the other side, Kraemer distinguishes, that there are the 'naturalist religions of trans-emperical realization' which is meant that 'man conceives all his efforts of meditation, religious practices, concentration, asceticism, etc. as means towards realizing and grasping the identity of his real self with divine reality.' Although this will not imply that those religions did not rely upon some sort of sacred book or secret text that is more or less distinctly considered a revelation. ${ }^{27}$ The prophetic religions are wholly theocentric, and 'the God who is the all-dominant and all-radiating centre is the personal, living God, who creates, speaks, commands, comforts, acts and saves; He is

\footnotetext{
24 Kraemer, The Christian Message, 70.

25 Ibid., 70-72.

26 Kraemer, Religion and the Christian Faith, 144-145.

27 Kraemer, The Christian Message, 143, also note 1.
} 
above nature, time and history and yet works mightily in nature, time and history.' And 'empirical Christianity has stood and stands under continuous and direct influence and judgement of the revelation in Christ', says Kraemer, and is 'in virtue thereof in a different position from the other religions. ${ }^{28}$ In the confrontation between the christian or missionary and the non-christian believer Kraemer states:

The prime and principal question for a Christian and a missionary, however, is to try all his life to see the non-Christian faiths under the light of the revelation in Christ; and then the highest commandment is not to be generous or ungenerous, to be tolerant and sympathetic or intolerant and harsh, but to be obedient to the light that shines in Christ, who is "grace and truth" from God but whom "the world" does not recognize intuitively. ${ }^{29}$

That means from the standpoint of 'the revelation in Christ, who is the measure of all things the "dialectical" approach, which is included in the view that the revelation in Christ has of all human existence, is the only right one by means of which to acquire a true and adequate insight.' Kraemer states that 'man remains all his life a humble and stumbling learner of what the revelation in Christ really implies, and accordingly remains also continuously a learner in the field of the great faiths of mankind. ${ }^{30}$ In other words: Christ is the measure of true religion, not in some way the general $a$ priori by which Christ had to be measured. For the Christian Christ is the religious a priori. Non-Christians and or non-believers will disavow this, but, Kraemer states: but one has to keep in mind that their decision for their religious a priori is just as much an act of faith as the Christian's choice for Christ. ${ }^{31}$

\footnotetext{
28 Ibid., 143, 145.

29 Ibid., 145.

$30 \quad$ Ibid., 146-7.

31 Kraemer, Religion and the Christian Faith, 145-146. At this point I like to mention to Karl Barth famous and controversial statement: 'Gottes Offenbarung als Aufhebung der Religion'
} 
In line with Karl Barth, Kraemer states that the reality and also the possibility of God's revelation, what means God's self-disclosure to men, 'belong exclusively to God's domain'. This domain depends only on God and not on man. But in this event of revelation there are two parties: God the agent and men who receives what is to be revealed. Barth stresses: 'Revelation is God's sovereign dealing with Man, or it is not revelation.' So revelation is exclusively divine reality and possibility. God's revelation to man comes in the shape of human experience, human words and action. God's revelation to man has a 'human face', Kraemer says. There are human psychological and historical structures. Otherwise there could be no Christian religion. In the other religions there are similarities, which are not unique, but has a peculiar character, what Barth calls not unique but peculiar (nicht einzigartig sondern enigartig). ${ }^{32}$

Why the Reformed missiology can rely on Barth's statement that religion is unbelief, and therefore all religions are concern of godless (gottlos) man? For this people who might have an intuition (German: Ahnung) of God's holiness, or a fearing of falling in the hands of the living God. Kraemer states: 'Man wants God, but somehow he wants Him his own way. Therefore

\footnotetext{
Which Kraemer translates as: God's revelation as the annulment of religion.' This statement is much discusses among theologians since Kraemer. In line with John Calvin Barth stresses that all human 'Religion' is Unglaube, unbelief, idolatry. Barth's conclusion is 'the Man as homo religious cannot be seen as if he were served from God and could be understood as a being in himself.' (Kraemer, Religion and the Christian Faith, 187-188). In his study Religion and the Christian Faith Kraemer leans heavily on Emile Brunner. Who comes close to John Calvin with his idea of sensus divinitatis, the ability of gasping the revelation of God and equipped with possibility of believing to God. It is uncertain if Barth mentioned with the term 'Aufhebung der Religion' to abolition, of annulment of all human religion, or 'Zurückname', abrogation. Or even in the sense of elevation. It is the question among modern missiologists if (parts of) human religion can be 'elevated' to the level that fits with God purpose of religion, namely to serve the glory of his Name. (see Kraemer, Religion and the Christian Faith, 188- Both Barth and Brunner had a sharp discussion about this item. Kraemer agrees with Barth on his statement that religion is unbelief, only in the light of the justification impii, the justification of the wicked, which is totally God's grace and His initiative. (Kraemer, Religion and the Christian Faith, 189).

32 Kreamer, Religion and the Christian Faith, 186.
} 
the deepst Ahnungen, the highest flights, the sincerest contrition, remain in the sphere of a lofty moralism or spirituality.' Christ demands, if we take the Biblical revelation seriously, a 'rectilinear transition from the world of religion.' Kraemer points to the words of the gospel of Mark 1:15:

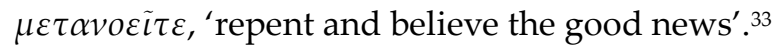

\section{Revelation, The Covenant and Religion(s)}

Finally I like to combine the idea of covenant with the ultimate goal of God's revelation. As we found that in the covenantal relation, the treaty-king was expecting things from the other partner in the relationship. In the terms of the stipulations, the covenant-keepers are hold to be responsible for answering to the treaty-God with trust, love and genuine faithfulness, simply because it is utterly the reasonable duty of this covenantal relationship. It seems to me that the basic idea of any religion can only be the revelation of God. While we see that older covenants have passed away, the basic idea remains the same. In Hebrews 6:13-18 is stated that the promises and stipulations have not been changed since Abraham, "because God wanted to make the unchanging nature of his purpose very clear to the heirs of what was promised, he confirmed it with an oath."

The ultimate requirements of man in according to God's revelation are, according to the Westminster Confession, chapter 7: “Man, by his fall, having made himself incapable of life by that covenant, the Lord was pleased to make a second, commonly called the covenant of grace; wherein He freely offers unto sinners life and salvation by Jesus Christ; requiring of them faith in Him, that they may be saved, and promising to give unto all those that are ordained unto eternal life His Holy Spirit, to make them willing, and able to believe." This implies at least the saving, eternal life and

33 Ibid., 336, 338. 
the life according to God's will, and the means to achieve this blessings by faith. Essential in any revelation, also in God's unique revelation to prophets and apostles and finally in Christ is the answer of creatures. ${ }^{34}$

In a publication in Dutch, scholars pointing to several (world) religions and claiming the deepest aim of any religion is the answer of man to God, god, the deity or the ultimate reality. ${ }^{35}$ This publication is not a handbook about the great living religions, but we find a description of the actual religious reality, mainly in the five great religions in perspective. Definitely these religions have a history and are rooted in a tradition. The contributors of the study are convinced that all these different religions are one in the aspect: they can be viewed as a unity. The main subject which is uniting all religious phenomena is the aspect of answer. It is not necessary to state that the idea of an answer to any revelation of God is also the core of religion. In the flow of history we see the widest range of answers people have given to God's revelation. The most fundamental topic of religion, will help lead one to a right view of the essence of religion, based on God's revelation. Like Christianity all the religions seeks answers of the four big questions in life:

1. The Origin of life - where did we come from?

2. The Ethics in daily life - how should we live?

3. The Meaning of life - what is the purpose for our life?

4. What is the Destiny of man - where is mankind heading?

In the pluralist view of the theology of religion we can hear the catchphrase: all the religious roads lead to the top of the mountain. Notwithstanding all the similarities in the religions of the world, there are a lot of differences, caused by the freedom people take for formulating their own religious

\footnotetext{
34 Michael Horton, Introducing Covenant Theology, 80-3.

35 J. Sperna Weiland, red. Antwoord, gestalten van geloof in de wereld van nu, (Amsterdam: Meulenhoff, 1989), (Answer, the appearances of faith in this world).
} 
answer. At this point Barth and Kraemer were right. One can never find unity in religion if one searches for the unity in all the religious phenomena. The core of the 'real' religion is the very source: God's revelation in Christ. That means based on this supposition the biblical idea of the covenant obliges us to focus on the heart of religion according to God's purpose. That means, Paul says in 2 Corinthians 10:5, We demolish arguments and every pretension that sets itself up against the knowledge of God, and we take captive every thought to make it obedient to Christ. The right answer to God's covenant, his promises and requirements, is an ongoing task for man created in His image: the true religion. On the other hand we find in this world a broad variety of religions, which could be as Karl Barth says: religions of unbelief, in term of a covenant: not the proper answer to God. The final decision whether a contemporary religion is true or false is therefore based on the only cardinal point which is given, or rather, revealed by God to man: his revelation to prophets and apostles, and finally in Christ. We can talk about interpretation of this revelation, about hermeneutics and forms of religiosity. We as man, in covenantal terms the lesser party in God's treaty are not given to establish the standard of true religion as answer to God. But the Bible as the witness of prophets and apostles about Christ is true and which has the authority as the Word of God. Scriptures never can be proven as God's Word. By the illumination of the Holy Spirit, we call the testimonium spiritus sancti, we can conclude: this is God's Word, the inspired Word of God. The idea of the covenant in Scripture as God's revelation is a great momentum for the development of the religion which is true in the face of triune God. 